Hydrol. Earth Syst. Sci., 17, 4177-4187, 2013

www.hydrol-earth-syst-sci.net/17/4177/2013/

doi:10.5194/hess-17-4177-2013

(c) Author(s) 2013. CC Attribution 3.0 License.

\title{
A worldwide analysis of trends in water-balance evapotranspiration
}

\author{
A. M. Ukkola ${ }^{1,2}$ and I. C. Prentice ${ }^{1,3}$ \\ ${ }^{1}$ Department of Biological Sciences, Macquarie University, North Ryde, NSW 2109, Australia \\ ${ }^{2}$ CSIRO Water for a Healthy Country Flagship, Black Mountain, ACT 2601, Australia \\ ${ }^{3}$ AXA Chair of Biosphere and Climate Impacts, Department of Life Sciences and Grantham Institute for Climate Change, \\ Imperial College, Silwood Park, Ascot SL5 7PY, UK
}

Correspondence to: A. M. Ukkola (anna.ukkola@students.mq.edu.au)

Received: 23 April 2013 - Published in Hydrol. Earth Syst. Sci. Discuss.: 3 May 2013

Revised: 9 September 2013 - Accepted: 17 September 2013 - Published: 25 October 2013

\begin{abstract}
Climate change is expected to alter the global hydrological cycle, with inevitable consequences for freshwater availability to people and ecosystems. But the attribution of recent trends in the terrestrial water balance remains disputed. This study attempts to account statistically for both trends and interannual variability in water-balance evapotranspiration (ET), estimated from the annual observed streamflow in 109 river basins during "water years" 19611999 and two gridded precipitation data sets. The basins were chosen based on the availability of streamflow time-series data in the Dai et al. (2009) synthesis. They were divided into water-limited "dry" and energy-limited "wet" basins following the Budyko framework. We investigated the potential roles of precipitation, aerosol-corrected solar radiation, land use change, wind speed, air temperature, and atmospheric $\mathrm{CO}_{2}$. Both trends and variability in ET show strong control by precipitation. There is some additional control of ET trends by vegetation processes, but little evidence for control by other factors. Interannual variability in ET was overwhelmingly dominated by precipitation, which accounted on average for $54-55 \%$ of the variation in wet basins (ranging from 0 to $100 \%$ ) and $94-95 \%$ in dry basins (ranging from 69 to $100 \%$ ). Precipitation accounted for $45-46 \%$ of ET trends in wet basins and $80-84 \%$ in dry basins. Net atmospheric $\mathrm{CO}_{2}$ effects on transpiration, estimated using the Land-surface Processes and eXchanges (LPX) model, did not contribute to observed trends in ET because declining stomatal conductance was counteracted by slightly but significantly increasing foliage cover.
\end{abstract}

\section{Introduction}

Climate change is expected to alter the global hydrological cycle (Huntington, 2006), shifting the timing and distribution of freshwater resources (Kundzewicz et al., 2008) and changing the balance between precipitation, runoff and evapotranspiration (Zhang et al., 2012). Climatic effects may be compounded by changes in vegetation, whether due to land use/land cover change or vegetation physiological, compositional and structural responses caused by climate change or increasing atmospheric $\mathrm{CO}_{2}$. Together these effects have the potential to change the amount of water available to the biosphere and for human use. Such changes have particular significance in regions already suffering from water deficits.

Evapotranspiration (ET) is the sum of evaporation from soil and open water, interception loss and plant transpiration. It is a key ecosystem variable linking hydrological, energy and carbon cycles and amounts to up to $60 \%$ of global land precipitation (Oki and Kanae, 2006; Teuling et al., 2009). Because ET cannot be measured directly, multiple methods for estimating actual and potential ET have been employed, including satellite retrieval methods based on air temperature, net radiation and/or vegetation indices (Wang and Dickinson, 2012), eddy covariance measurements of latent heat flux (e.g. Baldocchi et al., 2001), radiation-based calculations (Xu and Singh, 2000), and pan evaporation measurements (Brutsaert, 2006; Roderick and Farquhar, 2002). There are few longterm, large-scale observational data sets that can be used to analyse variations in ET, and the situation is exacerbated by disagreements among estimates of ET obtained by different methods (Zhang et al., 2012). Many studies have attempted to account for recent historical trends in the hydrological cycle, 


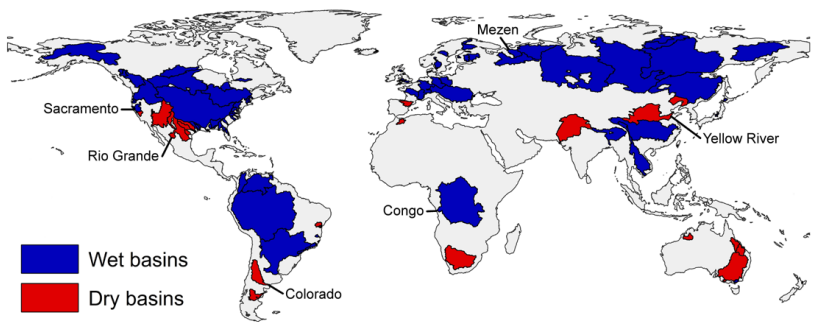

Fig. 1. Map of the study basins, classified into wet and dry according to aridity index (Sect. 2.1). The basins indicated are those used as examples in Fig. 4.

usually with runoff as the principal variable of interest (e.g. Dai et al., 2009; Gedney et al., 2006; Gerten et al., 2008; Labat et al., 2004; Piao et al., 2007), but no consensus on causation has emerged (Alkama et al., 2011). The direction of historical trends in runoff has also remained unclear, with Dai et al. (2009) and Milliman et al. (2008) finding a predominantly negative or non-existent trend across a large number of river basins, in contrast to an increase in global runoff reported by Labat et al. (2004). However, the data set of Labat et al. (2004) has been criticised, particularly for the wavelet method used to reconstruct the runoff time series (Legates et al., 2005; Peel and McMahon, 2006).

Many studies have recognised the importance of climate variability and trends, particularly in precipitation (e.g. Alkama et al., 2010; Dai et al., 2009; Gerten et al., 2008; Milliman et al., 2008), as drivers of changes in ET and/or runoff. Gerten et al. (2008) attributed $70 \%$ of a simulated runoff increase over the 20th century to climate (precipitation and air temperature) based on the LPJmL vegetation model (Bondeau et al., 2007; Rost et al., 2008; Sitch et al., 2003). Piao et al. (2007) reported a value of $53 \%$ using the ORCHIDEE biosphere model (Krinner et al., 2005). Other postulated climatic drivers of ET include solar shortwave radiation (particularly global "dimming" and "brightening" due to changes in aerosol loading; Roderick and Farquhar, 2002; Wild et al., 2008) and wind speed (McVicar et al., 2012), both of which influence evaporative demand and therefore ET. Changes to land-surface properties have also been invoked to account for historical runoff trends (Gedney et al., 2006; Piao et al., 2007). Deforestation decreases transpiration and interception losses (Bradshaw et al., 2007; Gordon et al., 2005) and consequently increases runoff (Bosch and Hewlett, 1982), if precipitation is unchanged. In dry areas, on the other hand, the expansion of croplands has been made possible by widespread irrigation, which increases water availability for ET and therefore tends to reduce runoff (Gordon et al., 2005), if precipitation is unchanged (the qualifications are important because deforestation can also lead to reduced rainfall while irrigation can increase it; D'Almeida et al., 2007; Lo and Famiglietti, 2013). Piao et al. (2007) concluded that land use change can account for about $50 \%$
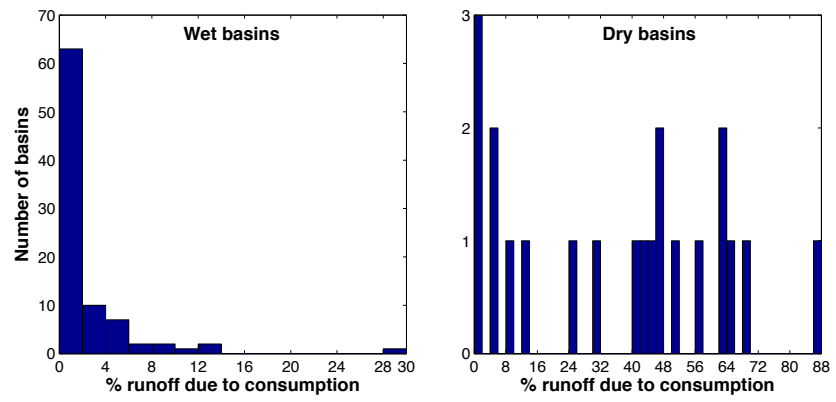

Fig. 2. The mean proportion of annual runoff (in \%) due to consumption in wet and dry basins.

of global reconstructed runoff trends, but this has been contested (e.g. by Alkama et al., 2011). Rising atmospheric $\mathrm{CO}_{2}$ concentration also can indirectly change ET and runoff via two opposing processes: partial stomatal closure which tends to reduce transpiration (Gedney et al., 2006; Sellers et al., 1996) and compensating increases in foliage cover, which tend to increase it (Betts et al., 1997). The net effect of rising atmospheric $\mathrm{CO}_{2}$ on runoff trends is disputed (e.g. Alkama et al., 2011; Gedney et al., 2006; Gerten et al., 2008; Piao et al., 2007). It remains unclear, based on published analyses, whether or not changes in vegetation structure and function have left a detectable imprint on runoff. Studies focusing on ET have variously relied on trends in pan evaporation (Brutsaert, 2006; McVicar et al., 2012; Roderick and Farquhar, 2002, 2004), empirical equations (Wang et al., 2010; Zeng et al., 2012; Zhang et al., 2012) or land surface models (Douville et al., 2012; Li and Mölders, 2008; Teuling et al., 2009). But pan measurements are only very indirectly related to actual ET, while model simulations and empirical calculations are uncertain and produce a large range of estimates (Mueller et al., 2011; Zhang et al., 2012).

This study aims to account for trends and interannual variability in ET during the period 1961-1999. Despite uncertainties afflicting both precipitation and streamflow data, the difference between these two variables (the "water balance ET") integrated over a catchment remains the most firmly observationally based estimator of ET. We use the Dai et al. (2009) synthesis for streamflow data, and two alternative gridded precipitation data sets in order to take some account of precipitation uncertainties. We consider all the proposed drivers of annual ET, relying on observational data sets where possible, but with transient foliage cover and stomatal conductance simulated by the Land Processes and eXchanges Dynamic Global Vegetation Model (LPX DGVM) (Prentice et al., 2011; Murray et al., 2011). In Sect. 2, we first describe the data sets, the LPX DGVM and analysis methods. Section 3 investigates (i) the interannual variability and (ii) trends in water balance ET and relates those to variability in potential drivers of ET. Finally, conclusions are presented in Sect. 4. 
Table 1. The proportion of interannual variability explained by all predictor variables and precipitation only (expressed as $R^{2}$ ), and the unique effect of meteorological and land surface variables as inferred from variance partitioning (expressed as adj. $R^{2}$ ) across wet and dry basins using CRU- and GPCC-based ET and precipitation, respectively.

\begin{tabular}{lrrrr}
\hline & \multicolumn{2}{c}{ Wet } & \multicolumn{2}{c}{ Dry } \\
\hline Predictor & CRU & GPCC & CRU & GPCC \\
\hline All variables & $66 \%$ & $68 \%$ & $96 \%$ & $96 \%$ \\
Precipitation & $54 \%$ & $55 \%$ & $95 \%$ & $94 \%$ \\
\hline Unique effect: & & & & \\
Meteorological & $35 \%$ & $40 \%$ & $51 \%$ & $56 \%$ \\
Land surface & $2 \%$ & $3 \%$ & $1 \%$ & $1 \%$ \\
\hline
\end{tabular}

\section{Methods}

\subsection{Study basins}

The study basins were chosen based on the availability of monthly river discharge data from Dai et al. (2009) so that spatial and temporal coverage could be maximised. Altogether 109 basins were chosen, covering approximately $33 \%$ of the unglaciated land surface (Fig. 1). Only basins with $\leq 10$ missing months during 1961-1999 were included in the analysis; gaps in the data were filled by linear interpolation between the values for the same month in the year before and the year after the gap. Basin boundaries were acquired from the Global Runoff Data Centre (GRDC; http: //grdc.bafg.de/), Geoscience Australia National Catchment Boundaries v.1.1.3. (http://www.ga.gov.au/), the US Geological Survey HYDRO1k project (Peel et al., 2010) and the European Environment Agency (http://www.eea.europa.eu/ data-and-maps/data/european-river-catchments-1).

The basins were divided into "energy-limited" (wet) and "water-limited" (dry) basins according to the Budyko framework (Budyko, 1974; Donohue et al., 2007; Li et al., 2013) (Fig. 1). This separation was achieved using the climatological aridity index $A\left(A=E_{\mathrm{p}} / P\right.$, where $E_{\mathrm{p}}=$ annual mean potential ET and $P=$ annual mean precipitation), averaged over the basin area. Basins with $A \leq 1.5$ were classified as "wet" and those with $A>1.5$ as "dry" (Zhang et al., 2012). A value of $A$ was calculated for each basin based on 1961-1999 mean values of precipitation in the Climatic Research Unit (CRU) TS 3.1 archive at $0.5^{\circ}$ resolution (Harris et al., 2013). $E_{\mathrm{p}}$ for each basin was calculated using the Priestley-Taylor method as in Gallego-Sala et al. (2010), using 1961-1999 mean values of cloud cover and air temperature from CRU TS 3.1. The Priestley-Taylor method has been shown to be appropriate for large-scale potential ET estimates (Raupach, 2000, 2001) and has been employed in other catchment-scale studies (e.g. Guerschman et al., 2009; Zhang et al., 2004).
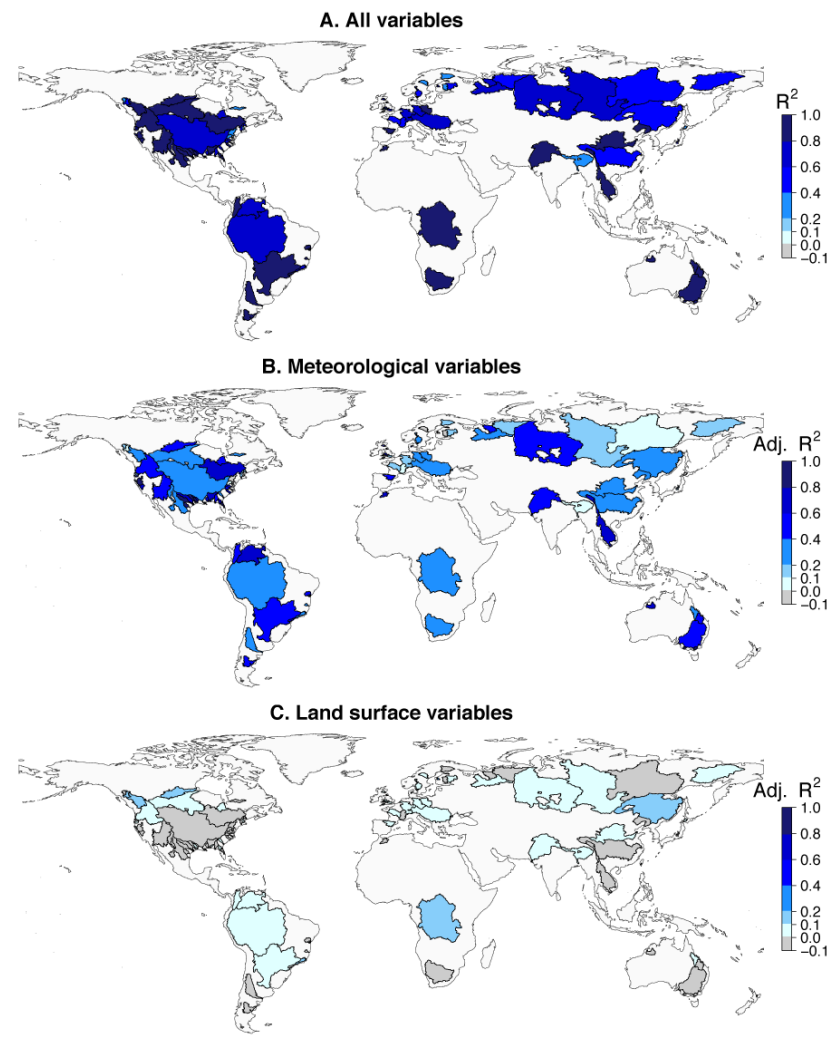

Fig. 3. The proportion of interannual variability in water balance ET explained by all predictor variables in each basin (A); and the unique effect of meteorological (B) and land surface $(\mathbf{C})$ variables in controlling ET variability, determined by variance partitioning. All values shown are based on CRU precipitation.

\subsection{Data}

Observed river discharge data (converted to runoff units) were acquired from the Dai et al. (2009) data set, which includes monthly streamflow at the farthest downstream gauging stations for the world's 925 largest river basins during the period 1900-2006. The data were compiled by Dai et al. (2009) mainly from Global Runoff Data Centre (GRDC), University of New Hampshire (UNH) and National Center for Atmospheric Research (NCAR) records. As the observed streamflow records are likely to include changes due to human disturbances (dams and water withdrawals), monthly water consumption estimates from the Global Water Use (GWU) model nested in the WaterGAP-2 model (Alcamo et al., 2003) were added to the observed runoff values. GWU estimates consumption based on three submodels for agricultural, industrial and domestic water use sectors at $0.5^{\circ}$ spatial resolution. The correction is minimal in the majority of wet basins, with consumption accounting for $2 \%$ of runoff on average (ranging from 0 to $29 \%$; Fig. 2). This leads to an average reduction of $2 \%$ in annual water balance ET estimates. In dry basins, the correction amounts to $37 \%$ of annual runoff 

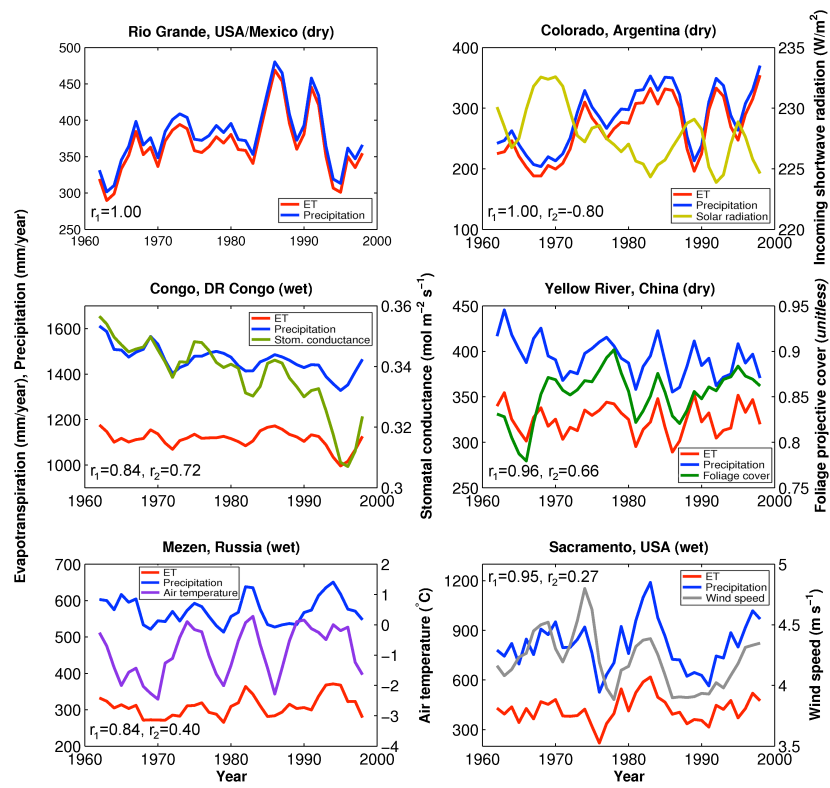

Fig. 4. Examples of interannual variability in water balance ET and its relationship with precipitation, solar radiation, stomatal conductance, foliage cover, air temperature and wind speed. Three-year block averages were used to smooth time series. Correlation coefficients for ET against precipitation $\left(r_{1}\right)$ and the second plot variable $\left(r_{2}\right)$ are shown. The location of each basin is indicated in Fig. 1.

on average (varying from 0 to $87 \%$; Fig. 2), but since runoff generally only forms a small component of the water balance in dry basins, a large relative change in runoff translates to a much smaller change in ET estimates. As such, the correction leads to an average reduction of $12 \%$ in ET.

Water balance ET was calculated as the difference between observed annual precipitation and runoff. Water year (October-September) totals were used to account for the effects of water storage in snowpacks during Northern Hemisphere winter. The water balance method has the advantage of being based on observations but assumes negligible changes in soil water storage. Two ET values were calculated for each basin using two alternative precipitation data sets from the CRU TS 3.1 archive (Harris et al., 2013) and Global Precipitation Climatology Centre (GPCC) Full Data Reanalysis Product v.4 (Rudolf et al., 1994; Schneider et al., 2008; http://www.esrl.noaa.gov/psd/data/gridded/data. gpcc.html). Both precipitation data sets are gridded at $0.5^{\circ}$ spatial resolution and were produced by three-dimensional interpolation of station data from multiple sources. Neither data set has been corrected for the possible effects of gauge undercatch.

Gridded monthly air temperature data at $0.5^{\circ}$ spatial resolution were obtained from the CRU TS 3.1 archive. Monthly near-surface $(10 \mathrm{~m})$ wind speed data were acquired from National Centres for Environmental Prediction (NCEP) reanalysis product (NOAA-CIRES Climate Diagnostics Cen- ter, Boulder, Colorado, http://www.cdc.noaa.gov/) regridded to $0.5^{\circ}$ from the original NCEP spatial resolution of $1.875^{\circ}$ using bilinear interpolation (Prentice et al., 2011).

Downwelling shortwave radiation data were obtained from the EU WATCH Forcing Data archive (Weedon et al., 2011). These data are based on European Centre for Medium-Range Weather Forecasts reanalysis (ERA-40) data (Uppala et al., 2005). They provide daily values for the period 1901-2009, adjusted for observed cloud cover and modelled aerosol optical depths (based on representations of sulfate, black carbon, mineral dust, sea salt, biomass burning and secondary organic aerosols (Bellouin et al., 2007)).

Land use data were acquired from the HYDE v3.1 database of Klein Goldewijk (2001), which describes "pasture" (including rangeland) and cropland extent at $0.5^{\circ}$ spatial resolution for the period 1700-2000 expressed as a fraction of each grid cell. Pasture and cropland extent were determined from historical data on agricultural activities using population density as a proxy for location (Klein Goldewijk and Ramankutty, 2004). The data were linearly interpolated to annual timescale from the original decadal time step (Prentice et al., 2011).

All daily or monthly data were converted to water year totals. Basin-specific values were extracted from each gridded variable using a point-based method, whereby cells with their centres within the catchment boundaries were selected.

\subsection{LPX model}

Dynamic global vegetation models (DGVMs) can represent time-dependent variations in ecosystem composition (in terms of plant functional types), structure (including height, biomass, leaf area index and foliage projective cover) and function (including gross and net primary production, ET and runoff) (Murray et al., 2013; Prentice and Cowling, 2013). The LPX DGVM (Prentice et al., 2011) is a development of the Lund-Potsdam-Jena (LPJ) model (Sitch et al., 2003; Gerten et al., 2004) with improved fire dynamics (Prentice et al., 2011). The model makes use of a photosynthesiswater balance scheme that explicitly couples $\mathrm{CO}_{2}$ assimilation with transpiration (Gerten et al., 2004) but does not include nutrient constraints on assimilation. LPX has been evaluated against global and local hydrological data (Gerten et al., 2004; Murray et al., 2011; Ukkola and Murray, 2013) as well as a comprehensive set of vegetational, atmospheric and hydrological benchmarks (Kelley et al., 2012). The hydrological component is detailed in Gerten et al. (2004). A full description of the vegetation and carbon dynamics can be found in Sitch et al. (2003). Here we provide a brief discussion on the processes directly influencing ET in the model.

Stomatal conductance $\left(g_{\mathrm{c}}\right)$ is determined based on daytime assimilation rate $\left(A_{\mathrm{dt}}\right)$, ambient $\mathrm{CO}_{2}$ concentration $\left(c_{\mathrm{a}}\right)$ and a plant functional type (PFT) specific minimum canopy 
A. Precipitation

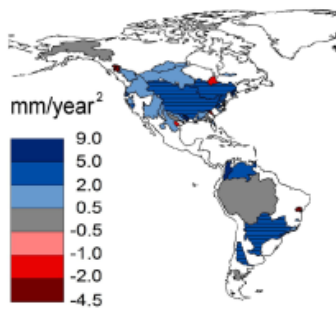

C. Water balance evapotranspiration

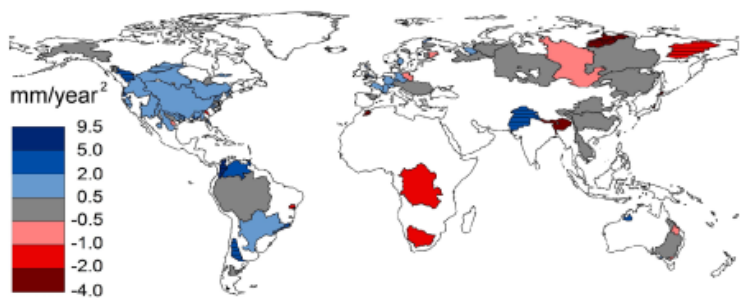

E. Wind speed

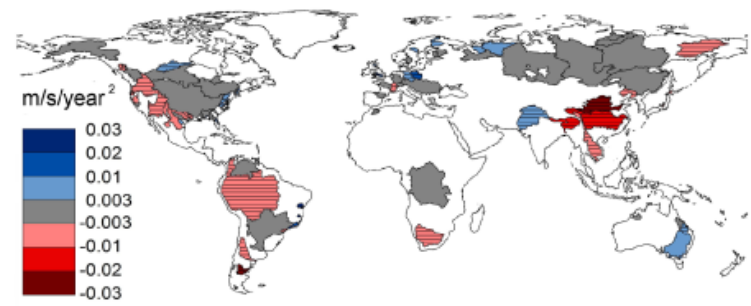

G. Cropland extent

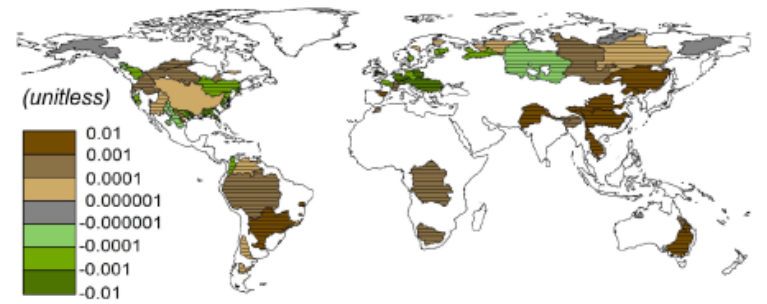

I. Foliage projective cover

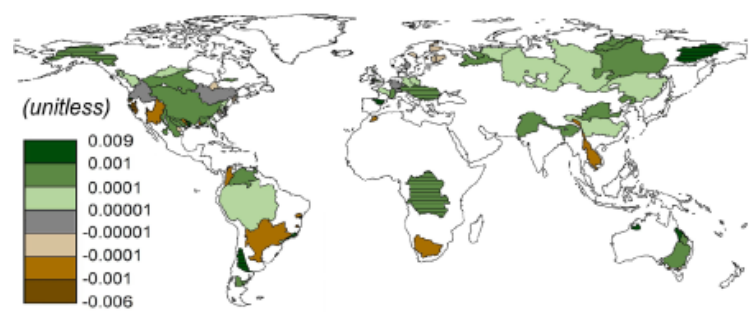

B. Runoff

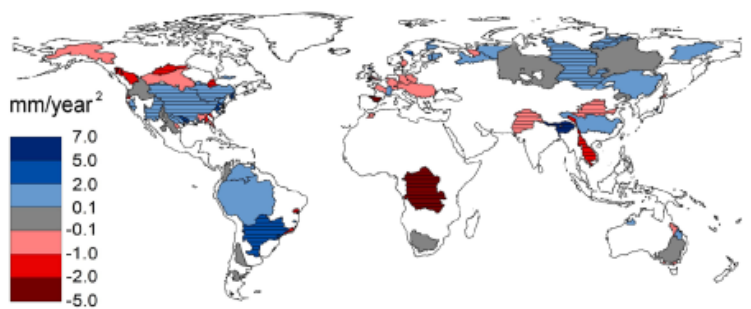

D. Shortwave radiation

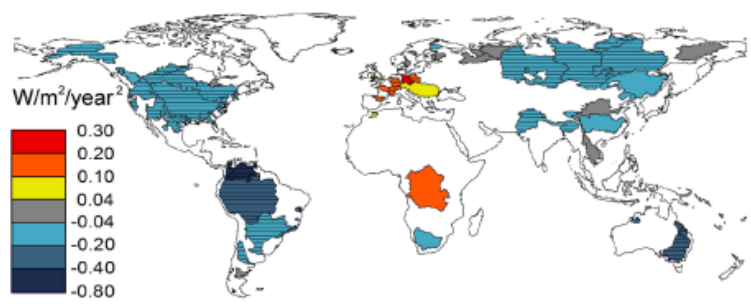

F. Surface air temperature

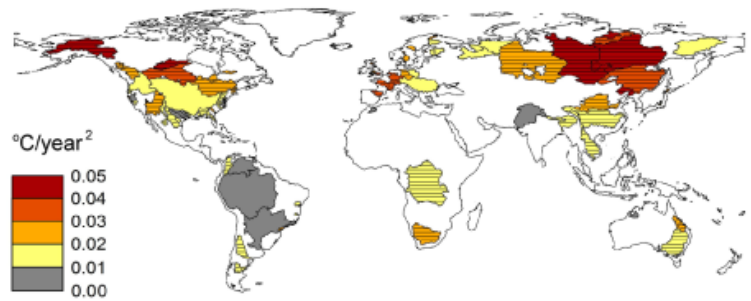

H. Pasture extent

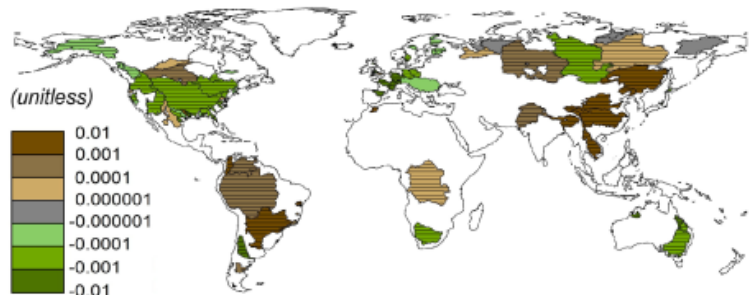

J. Stomatal conductance

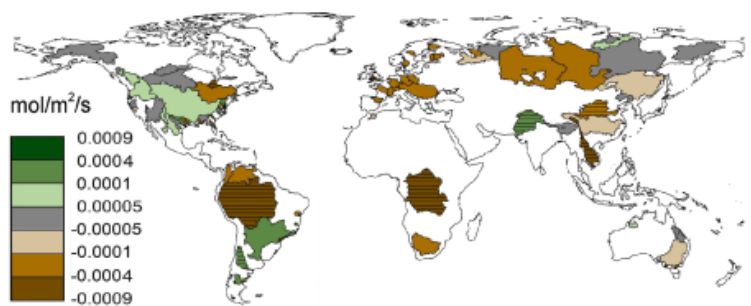

Fig. 5. Trends in observed CRU TS 3.1 precipitation, runoff, CRU-based water balance ET, solar radiation, wind speed, air temperature and land cover, and modelled stomatal conductance and foliage cover. Basins with significant trends are shown shaded.

conductance $\left(g_{\min }\right)$ :

$g_{\mathrm{c}}=g_{\min }+\frac{1.6 A_{\mathrm{dt}}}{c_{\mathrm{a}}(1-\lambda)}$

where $\lambda$ takes a maximum value of 0.8 for $\mathrm{C}_{3}$ and 0.4 for $\mathrm{C}_{4}$ plants. When soil water supply is limiting, $g_{\mathrm{c}}$ is reduced in such a way as to be consistent with Monteith's (1995) empirical formulation of the relationship between ET and $g_{\mathrm{c}}$. The fractional foliage projective cover (FPC) for PFT is calculated annually as a function of total crown area (CA), plant population density $(P)$ and the average individual FPC (Sitch 
Table 2. Attribution of water balance ET trends (in $\mathrm{mm} \mathrm{yr}^{-2}$ ) in wet basins based on coefficients and $p$ values from a multiple regression analysis, using CRU- and GPCC-based ET and precipitation, respectively. Significant $p$ values $(\leq 0.05)$ and coefficients are in italics.

\begin{tabular}{|c|c|c|c|c|}
\hline & CRU & GPCC & CRU & GPCC \\
\hline Predictor & \multicolumn{2}{|c|}{ Coefficient } & \multicolumn{2}{|c|}{$p$ value } \\
\hline Precipitation $\left(\mathrm{mm} \mathrm{yr}^{-2}\right)$ & 0.49 & 0.51 & 0.000 & 0.000 \\
\hline Shortwave radiation $\left(\mathrm{W} \mathrm{m}^{-2} \mathrm{yr}^{-2}\right)$ & -0.97 & 0.02 & 0.489 & 0.991 \\
\hline Wind speed $\left(\mathrm{m} \mathrm{s}^{-1} \mathrm{yr}^{-2}\right)$ & 7.98 & -5.53 & 0.671 & 0.764 \\
\hline Air temperature $\left({ }^{\circ} \mathrm{C} \mathrm{yr}^{-2}\right)$ & 1.62 & 3.40 & 0.930 & 0.851 \\
\hline Pasture & 62.59 & 38.49 & 0.516 & 0.688 \\
\hline Cropland & 93.87 & -20.30 & 0.413 & 0.859 \\
\hline LPX-simulated foliage cover & 340.85 & 125.48 & 0.040 & 0.428 \\
\hline $\begin{array}{l}\text { LPX-simulated stomatal conductance } \\
\left(\mathrm{mol} \mathrm{m}^{-2} \mathrm{~s}^{-1} \mathrm{yr}^{-2}\right)\end{array}$ & -288.47 & -232.18 & 0.658 & 0.718 \\
\hline
\end{tabular}

Table 3. The proportion of ET trends explained by all predictor variables and precipitation only (expressed as $R^{2}$ ) across wet and dry basins, using CRU- and GPCC-based ET and precipitation, respectively.

\begin{tabular}{lrrrr}
\hline & \multicolumn{2}{c}{ Wet } & \multicolumn{2}{c}{ Dry } \\
\hline & CRU & GPCC & CRU & GPCC \\
\hline All variables & $49 \%$ & $46 \%$ & $94 \%$ & $95 \%$ \\
Precipitation & $45 \%$ & $46 \%$ & $80 \%$ & $84 \%$ \\
\hline
\end{tabular}

et al., 2003):

$\mathrm{FPC}=\mathrm{CA} \cdot P \cdot \mathrm{FPC}_{\mathrm{ind}}$.

Total FPC, the measure used in this study, varies between 0 (bare ground) and 1. Annual average FPC has been found to compare favourably against remotely sensed observations of the fraction of absorbed photosynthetically active radiation (fAPAR) (Kelley et al., 2012).

Both $g_{\mathrm{c}}$ and FPC influence simulated actual ET. FPC determines the amount of transpiring foliage, and controls interception loss by altering canopy storage capacity. $g_{\mathrm{c}}$ controls plant transpiration rates by linking $\mathrm{CO}_{2}$ and water availabilities, so that transpiration is reduced at higher $\mathrm{CO}_{2}$ concentrations and/or limited water supply and vice versa.

\subsection{Model set-up}

The model was spun up for $7000 \mathrm{yr}$ using a repeating time series of detrended climate variables and stable $\mathrm{CO}_{2}$ at $280 \mathrm{ppm}$, until the $50 \mathrm{yr}$ means of the slow carbon pools varied by $<2 \%$ (as detailed in Prentice et al., 2011). The model was subsequently run in transient mode for the period 1850 2006, forced with monthly gridded fields of mean, maximum and minimum air temperature, precipitation and cloud cover from the CRU TS 3.1 archive, wet day frequency from the
CRU TS 3.0 archive and NCEP wind speed, together with global annually varying $\mathrm{CO}_{2}$ concentrations (Etheridge et al., 1996; IPCC, 2001). Soil properties are prescribed based on Zobler (1986).

\subsection{Analysis}

We investigated what controls interannual variability in ET by comparing it to variability in precipitation, solar radiation, air temperature, wind speed, land use and vegetation processes by means of multiple regression. Seven river basins (Anabar, Lagarfljot, Olenek, Santa Mariada, Skjern, Teno and Yukon), mainly situated in high northern latitudes, were excluded from this analysis as they have invariant (zero) pasture and/or cropland extent, rendering the regression analysis invalid. Coefficients of determination $\left(R^{2}\right)$ derived from the multiple regression analysis were used to indicate the proportion of variability in ET explained by the predictor variables.

Variance partitioning (Legendre and Legendre, 2012) was used to further attribute variability. Predictor variables were assigned to one of two categories: meteorological variables (precipitation, solar radiation, air temperature and wind speed) and land-surface variables (pasture and cropland extent, stomatal conductance and foliage cover). The method makes it possible to estimate the unique effect of the two sets of predictors. It partitions variance into four components: the unique contributions of the two sets of predictors, the common contribution of the two sets (the results of correlations among predictors) and residual (random) variation not accounted for by the predictors. The unique effect of meteorological predictors was estimated as the difference between adjusted $R^{2}$ values derived from a multiple regression analysis using (i) both sets of predictors and (ii) land surface variables only, and vice versa.

Trends were calculated using ordinary least-squares linear regression based on annual values for water years (precipitation, runoff, ET, solar radiation, wind speed, air temperature and stomatal conductance) or calendar years (cropland, 
Table 4. Attribution of water balance ET trends (in $\mathrm{mm} \mathrm{yr}^{-2}$ ) in dry basins based on coefficients and $p$ values from a multiple regression analysis, using CRU- and GPCC-based ET and precipitation, respectively. Significant $p$ values $(\leq 0.05)$ and coefficients are in italics.

\begin{tabular}{lrrrr}
\hline & \multicolumn{1}{c}{ CRU } & GPCC & CRU & GPCC \\
\hline Predictor & \multicolumn{2}{c}{ Coefficient } & \multicolumn{2}{c}{$p$ value } \\
\hline Precipitation $\left(\mathrm{mm} \mathrm{yr}^{-2}\right)$ & 0.87 & 0.88 & 0.000 & 0.000 \\
Shortwave radiation $\left(\mathrm{W} \mathrm{m}^{-2} \mathrm{yr}^{-2}\right)$ & 1.45 & 1.66 & 0.435 & 0.361 \\
Wind speed $\left(\mathrm{m} \mathrm{s}^{-1} \mathrm{yr}^{-2}\right)$ & 15.15 & 20.87 & 0.398 & 0.211 \\
Air temperature $\left({ }^{\circ} \mathrm{C} \mathrm{yr}^{-2}\right)$ & -1.22 & 3.43 & 0.931 & 0.809 \\
Pasture & 0.59 & -5.57 & 0.991 & 0.923 \\
Cropland & 131.05 & 125.61 & 0.255 & 0.276 \\
LPX-simulated foliage cover & 356.38 & 331.35 & 0.010 & 0.016 \\
LPX-simulated stomatal conductance & -2210.41 & -2007.65 & 0.082 & 0.121 \\
$\left(\mathrm{~mol} \mathrm{~m} \mathrm{~s}^{-1} \mathrm{yr}^{-2}\right)$ & & & & \\
\hline
\end{tabular}

pasture and foliage cover) for the period 1961-1999. To attribute trends in ET, a multiple regression of ET trends against those in predictor variables was performed, and coefficients and $p$ values derived from the analysis were used to indicate the sign and significance of the relationship between ET and predictor trends, respectively.

\section{Results and discussion}

\subsection{Interannual variability in water balance ET}

Interannual variability in ET in both wet and dry basins was found to be strongly controlled by variability in precipitation. On average, we were able to explain $66-68 \%$ of ET variability in wet basins (ranging from 13 to $100 \%$ ), and $96 \%$ in dry basins (ranging from 79 to $100 \%$ ) (Fig. 3a; Table 1), with precipitation accounting for most of this (54-55 and $94-95 \%$, respectively). The relationship to precipitation was particularly evident in the dry basins (see e.g. the Rio Grande and Colorado basins in Fig. 4) and precipitation and ET magnitudes are very similar (i.e. almost all precipitation is evaporated and runoff is close to zero). In wet basins, precipitation plays a slightly weaker role in controlling ET variability, as hypothesised based on the Budyko framework. ET nevertheless tracks changes in precipitation in the majority of basins (see the Congo, Mezen and Sacramento basins in Fig. 4), with the exception of some northern high-latitude basins, which may be prone to larger than average precipitation uncertainties due to snow undercatch.

Solar radiation might be expected to exert a strong control on ET because it is the main determinant of the energy available for evaporation (Hobbins, 2004; Oliveira et al., 2011; Teuling et al., 2009), particularly in "energy-limited" wet basins. However, we found no strong positive correlations between ET and solar radiation variability and conversely, solar radiation was often found to correlate negatively with ET, likely as a result of increased cloud cover being asso- ciated with wet years. This was particularly evident in dry basins, where radiation was strongly reduced during years of increased precipitation and vice versa (see the Colorado Basin in Fig. 4).

Other climate variables showed significant correlations with interannual variation in ET only in a minority of basins. Air temperature variation was important in some cold northern basins (see the Mezen Basin in Fig. 4). Wind speed correlated with ET in some small coastal basins (see the Sacramento Basin in Fig. 4). Stomatal conductance tracked changes in ET in some mainly subtropical and tropical basins (see Congo in Fig. 4), whereas FPC correlated with ET in some (mainly dry) basins (see Yellow River in Fig. 4). Cropland and pasture extents change gradually and show no significant effects on interannual variability in ET. Changes in soil moisture could in principle drive interannual variability in ET (as much as they are a consequence of it) (Seneviratne et al., 2010) but were ignored in the water balance method. However, we found no significant lags between precipitation and ET on annual timescales (not shown), suggesting that time-varying retention of water in soils did not compromise the results.

Variance partitioning was used to further attribute interannual variability in ET to establish the unique contributions of meteorological and land-surface variables. Meteorological variables were found to exert a strong unique control, due to the overwhelming importance of precipitation variability (Fig. 3b). On average, meteorological variables explained $35-40$ and $51-56 \%$ of ET variability in wet and dry basins, respectively (Table 1 ). However, meteorological variables were less important in some temperate northern and boreal regions, possibly as a result of greater precipitation uncertainties. Land-surface variables were found to be important in some cold and tropical regions but generally show a much weaker control on ET than meteorological variables (Fig. 3c). On average, land-surface variables only account for $2-3 \%$ of variability in wet and $1 \%$ in dry basins (Table 1 ). 
The basins where land-surface variables are significant tend to be forested, and some of them subject to wide-scale deforestation (e.g. Amazon and Congo) causing unusually large changes in the land surface.

\subsection{Trends in water balance ET}

Both positive and negative trends are observed in the water balance over the period 1961-1999 (Fig. 5). Precipitation, ET and runoff generally increased in the Americas, with some reductions in runoff in northern basins as a consequence of increased ET. Conversely, runoff and ET show reductions in Africa, likely as a result of a sharp decline in precipitation, particularly in the Congo Basin. Elsewhere, water balance trends are basin-dependent and where significant trends are present, ET and runoff have often changed in opposite directions, such as in parts of Siberia, Europe and India. Shortwave radiation decreased throughout the world, with the exception of Europe and parts of Africa (Fig. 5). No subsequent "brightening" was observed in North America, Australia or Asia during the period up to 1999. Wind speed decreased on the western coast of the Americas and Southeast Asia but changes elsewhere were slight. Air temperatures increased everywhere except in tropical South America. Land use changed almost throughout the world, with pasture expanding everywhere except North America and Europe and cropland expanding in most regions apart from Europe. Simulated FPC increased and stomatal conductance generally decreased, particularly in forested regions, as expected as a result of increasing atmospheric $\mathrm{CO}_{2}$.

In wet basins, observed trends in water balance ET are generally explained by precipitation and to some extent increased foliage cover (when CRU TS 3.1 based ET is used; Table 2), pointing to a small but significant effect of increased atmospheric $\mathrm{CO}_{2}$. Predictor variables can explain $46-49 \%$ of the ET trend, with precipitation alone accounting for $45-46 \%$ of the ET trend (Table 3). Other variables, including solar radiation, were not found to be significant predictors of the trend.

A previous study by Zhang et al. (2012) reported $R^{2}=9 \%$ for wet basins when water balance ET trends were compared to precipitation trends. Our analysis explains more of the ET trends than Zhang et al. (2012) but we are still only able to account for around half of the ET trends in wet basins. ET in wet basins may be inhibited by factors such as low vapour pressure deficit reducing evaporative demand. Soil moisture has been postulated as an important driver of ET (Jung et al., 2010) but was ignored in this study. However, other studies have shown soil moisture to be mainly driven by precipitation (Sheffield and Wood, 2008), which is explicitly included in our analysis. It is unlikely that not accounting for soil moisture trends results in major uncertainty. Data quality issues may also hinder attribution of trends, especially in sparsely populated tropical areas (Wohl et al., 2012). A stronger disagreement was found between CRU TS 3.1 and
GPCC precipitation trends in the tropics compared to the rest of the world (not shown). Some wet basins also showed negative annual ET totals during some years as well as low actual/potential ET ratios and actual ET exceeding potential ET, pointing to likely biases in the observations (Kauffeldt et al., 2013). However, the results were found not to be sensitive to these physically implausible data. Other predictor variables also have inherent uncertainties, particularly land use data for the pre-satellite era.

In dry basins, ET trends are mainly explained by precipitation, which accounts for 80-84\% of the trend (Tables 3, 4). This agrees well with findings of Zhang et al. (2012), who reported $R^{2}=85 \%$ for dry basins. In addition, increasing foliage cover shows a significant positive effect on ET trends, implying a net increase in transpiration and interception as a result of increased atmospheric $\mathrm{CO}_{2}$. This is in line with findings by Donohue et al. (2013) who reported a recent greening trend across the world's warm arid environments as a result of the $\mathrm{CO}_{2}$ fertilisation effect. Together, all variables account for $94-95 \%$ of the ET trend (Table 3).

\section{Conclusions}

Both trends and interannual variability in water balance ET are strongly controlled by precipitation. In the dry "water-limited" basins precipitation explains $80-95 \%$ of ET changes, compared to $45-55 \%$ in the wet basins. This conclusion was shown to be independent of the precipitation data set used, and it is consistent with the expectation of strong water limitation of ET in dry basins.

Vegetation processes were also found to influence ET. Foliage cover was found to be a significant control of ET trends in both wet and dry basins, and stomatal conductance variations correlated with the interannual variability of ET in some basins. Both stomatal conductance and foliage cover are expected to respond strongly to increasing atmospheric $\mathrm{CO}_{2}$ concentrations (e.g. Betts et al., 1997, 2007; Gedney et al., 2006; Sellers et al., 1996), but in opposite directions. With large increases in $\mathrm{CO}_{2}$ projected, it is likely that $\mathrm{CO}_{2}$ effects will become increasingly apparent, but the sign and regional pattern of these effects over the longer term is not well constrained by the available evidence to date.

Solar shortwave radiation was generally not found to be a significant predictor of ET variability. This is despite the expectation that energy-limited basins, particularly, should respond to changes in the driving force for ET. However, persistent large differences among different, satellite-based radiation data products (Zhang et al., 2012) may hinder the attribution of ET to solar radiation changes. Land use change effects on ET were not found to be significant. 
Acknowledgements. A. M. Ukkola is supported by an international Macquarie University Research Excellence scholarship and a CSIRO Water for a Healthy Country Flagship top-up scholarship. We thank Aiguo Dai for making the streamflow data publicly available. Lina Mercado drew our attention to the WATCH solar radiation data set, which is made available by the International Institute for Applied Systems Analysis, Austria.

Edited by: J. Liu

\section{References}

Alcamo, J., Döll, P., Henrichs, T., Kaspar, F., Lehner, B., Rösch, T., and Siebert, S.: Development and testing of the WaterGAP 2 global model of water use and availability, Hydrolog. Sci. J., 48, 317-337, 2003.

Alkama, R., Kageyama, M., and Ramstein, G.: Relative contributions of climate change, stomatal closure, and leaf area index changes to 20th and 21st century runoff change: A modelling approach using the Organizing Carbon and Hydrology in Dynamic Ecosystems (ORCHIDEE) land surface model, J. Geophys. Res., 115, D17112, doi:10.1029/2009jd013408, 2010.

Alkama, R., Decharme, B., Douville, H., and Ribes, A.: Trends in global and basin-scale runoff over the late twentieth century: methodological issues and sources of uncertainty, J. Climate, 24, 3000-3014, doi:10.1175/2010jcli3921.1, 2011.

Baldocchi, D., Falge, E., Gu, L., Olson, R., Hollinger, D., Running, S., Anthoni, P., Bernhofer, C., Davis, K., Evans, R., Fuentes, J., Goldstein A., Katul, G., Law, B., Lee, X., Malhi, Y., Meyers, T., Munger, W., Oechel, W., Paw U., K. T., Pilegaard K., Schmid, H. P., Valentini, R., Verma S., Vesala, T., Wilson, K., and Wofsy, S.: FLUXNET: A new tool to study the temporal and spatial variability of ecosystem-scale carbon dioxide, water vapor, and energy flux densities, B. Am. Meteorol. Soc., 82, 2415-2434, 2001.

Bellouin, N., Boucher, O., Haywood, J., Johnson, C., Jones, A., Rae, J., and Woodward, S.: Improved representation of aerosols for HadGEM2, Hadley Centre technical note 73, Exeter, United Kingdom, 42 pp., 2007.

Betts, R. A., Cox, P. M., Lee, S. E., and Woodward, F. I.: Contrasting physiological and structural vegetation feedbacks in climate change simulations, Nature, 387, 796-799, 1997.

Betts, R. A., Boucher, O., Collins, M., Cox, P. M., Falloon, P. D., Gedney, N., Hemming, D. L., Huntingford, C., Jones, C. D., Sexton, D. M. H., and Webb, M. J.: Projected increase in continental runoff due to plant responses to increasing carbon dioxide, Nature, 448, 1037-1041, doi:10.1038/nature06045, 2007.

Bondeau, A., Smith, P. C., Zaehle, S., Schaphoff, S., Lucht, W., Cramer, W., Gerten, D., Lotze-Campen, H., Müller, C., Reichstein, M., and Smith, B.: Modelling the role of agriculture for the 20th century global terrestrial carbon balance, Global Change Biol., 13, 679-706, doi:10.1111/j.13652486.2006.01305.x, 2007.

Bosch, J. M. and Hewlett, J. D.: A review of catchment experiments to determine the effect of vegetation changes on water yield and evapotranspiration, J. Hydrol., 55, 3-23, 1982.

Bradshaw, C. J. A., Sodhi, N. S., Peh, K. S. H., and Brook, B. W.: Global evidence that deforestation amplifies flood risk and severity in the developing world, Global Change Biol., 13, 2379-2395, doi:10.1111/j.1365-2486.2007.01446.x, 2007.
Brutsaert, W.: Indications of increasing land surface evaporation during the second half of the 20th century, Geophys. Res. Lett., 33, L20403, doi:10.1029/2006GL027532, 2006.

Budyko, M. I.: Climate and life, International Physics Series, Academic, New York, 1974.

Dai, A., Qian, T., Trenberth, K. E., and Milliman, J. D.: Changes in continental freshwater discharge from 1948 to 2004, J. Climate, 22, 2773-2792, doi:10.1175/2008JCLI2592.1, 2009.

D’Almeida, C., Vörösmarty, C. J., Hurtt, G. C., Marengo, J. A., Dingman, S. L., and Keim, B. D.: The effects of deforestation on the hydrological cycle in Amazonia: a review on scale and resolution, Int. J. Climatol., 27, 633-647, doi:10.1002/joc.1475, 2007.

Donohue, R. J., Roderick, M. L., and McVicar, T. R.: On the importance of including vegetation dynamics in Budyko's hydrological model, Hydrol. Earth Syst. Sci., 11, 983-995, doi:10.5194/hess11-983-2007, 2007.

Donohue, R. J., Roderick, M. L., McVicar, T. R., and Farquhar, G. D.: Impact of $\mathrm{CO}_{2}$ fertilisation on maximum foliage cover across the globe's warm, arid environments, Geophys. Res. Lett., 40, 3031-3035, doi:10.1002/grl.50563, 2013.

Douville, H., Ribes, A., Decharme, B., Alkama, R., and Sheffield, $\mathrm{J}$.: Anthropogenic influence on multidecadal changes in reconstructed global evapotranspiration, Nat. Clim. Change, 3, 59-62, doi:10.1038/nclimate1632, 2012.

Etheridge, D., Steele, L., Langenfelds, R., Francey, R., Barnola, J.M., and Morgan, V.: Natural and anthropogenic changes in atmospheric $\mathrm{CO}_{2}$ over the last 1000 years from air in Antarctic ice and firn, J. Geophys. Res., 101, 4115-4128, 1996.

Gallego-Sala, A. V, Clark, J. M., House, J. I., Orr, H. G., Prentice, I. C., Smith, P., Farewell, T., and Chapman, S. J.: Bioclimatic envelope model of climate change impacts on blanket peatland distribution in Great Britain, Clim. Res, 45, 151-162, doi:10.3354/cr00911, 2010.

Gedney, N., Cox, P. M., Betts, R. A., Boucher, O., Huntingford, C., and Stott, P. A.: Detection of a direct carbon dioxide effect in continental river runoff records, Nature, 439, 835-838, doi:10.1038/nature04504, 2006.

Gerten, D., Schaphoff, S., Haberlandt, U., Lucht, W., and Sitch, S.: Terrestrial vegetation and water balance - hydrological evaluation of a dynamic global vegetation model, J. Hydrol., 286, 249270, doi:10.1016/j.jhydrol.2003.09.029, 2004.

Gerten, D., Rost, S., von Bloh, W., and Lucht, W.: Causes of change in 20th century global river discharge, Geophys. Res. Lett., 35, L20405, doi:10.1029/2008g1035258, 2008.

Gordon, L. J., Steffen, W., Jönsson, B. F., Folke, C., Falkenmark, M., and Johannessen, Å.: Human modification of global water vapor flows from the land surface, P. Natl. Acad. Sci. USA, 102, 7612-7617, doi:10.1073/pnas.0500208102, 2005.

Guerschman, J. P., van Dijk, A. I. J. M., Mattersdorf, G., Beringer, J., Hutley, L. B., Leuning, R., Pipunic, R. C., and Sherman, B. S.: Scaling of potential evapotranspiration with MODIS data reproduces flux observations and catchment water balance observations across Australia, J. Hydrol., 369, 107-119, doi:10.1016/j.jhydrol.2009.02.013, 2009.

Harris, I., Jones, P. D., Osborn, T. J., and Lister, D. H.: Updated high-resolution grids of monthly climatic observations - the CRU TS3.10 Dataset, Int. J. Climatol., in press, doi:10.1002/joc.3711, 2013. 
Hobbins, M. T.: Trends in pan evaporation and actual evapotranspiration across the conterminous U.S.: Paradoxical or complementary?, Geophys. Res. Lett., 31, L13503, doi:10.1029/2004GL019846, 2004.

Huntington, T. G.: Evidence for intensification of the global water cycle: Review and synthesis, J. Hydrol., 319, 83-95, doi:10.1016/j.jhydrol.2005.07.003, 2006.

IPCC: Appendix II - SRES Tables', in: Climate Change 2001: The Scientific Basis. Contribution of Working Group I to the Third Assessment Report of the Intergovernmental Panel on Climate Change, edited by: Houghton, J. T., Ding, Y., Griggs, D. J., Noguer, M., van der Linden, P. J., Dai, X., Maskell, K., and Johnson, C. A., Cambridge University Press, Cambridge, UK and New York, NY, USA, 881 pp., 2001.

Jung, M., Reichstein, M., Ciais, P., Seneviratne, S. I., Sheffield, J., Goulden, M. L., Bonan, G., Cescatti, A., Chen, J., de Jeu, R., Dolman, A. J., Eugster, W., Gerten, D., Gianelle, D., Gobron, N., Heinke, J., Kimball, J., Law, B. E., Montagnani, L., Mu, Q., Mueller, B., Oleson, K., Papale, D., Richardson, A. D., Roupsard, O., Running, S., Tomelleri, E., Viovy, N., Weber, U., Williams, C., Wood, E., Zaehle, S., and Zhang, K.: Recent decline in the global land evapotranspiration trend due to limited moisture supply, Nature, 467, 951-954, doi:10.1038/nature09396, 2010.

Kauffeldt, A., Halldin, S., Rodhe, A., Xu, C.-Y., and Westerberg, I. K.: Disinformative data in large-scale hydrological modelling, Hydrol. Earth Syst. Sci., 17, 2845-2857, doi:10.5194/hess-172845-2013, 2013.

Kelley, D. I., Colin Prentice, I., Harrison, S. P., Wang, H., Simard, M., Fisher, J. B., and Willis, K. O.: A comprehensive benchmarking system for evaluating global vegetation models, Biogeosciences Discuss., 9, 15723-15785, doi:10.5194/bgd-9-157232012, 2012.

Klein Goldewijk, K.: Estimating global land use change over the past 300 years: The HYDE database, Global Biochem. Cy., 15, 417-433, doi:10.1029/1999GB001232, 2001.

Klein Goldewijk, K. and Ramankutty, N.: Land cover change over the last three centuries due to human activities: The availability of new global data sets, GeoJournal, 61, 335-344, doi:10.1007/s10708-004-5050-z, 2004.

Krinner, G., Viovy, N., de Noblet-Ducoudré, N., Ogée, J., Polcher, J., Friedlingstein, P., Ciais, P., Sitch, S., and Prentice, I. C.: A dynamic global vegetation model for studies of the coupled atmosphere-biosphere system, Global Biochem. Cy., 19, GB1015, doi:10.1029/2003GB002199, 2005.

Kundzewicz, Z. W., Mata, L., Arnell, N. W., Döll, P., Jimenez, B., Miller, K., Oki, T., Sen, Z., and Shiklomanov, I.: The implications of projected climate change for freshwater resources and their management, Hydrolog. Sci. J., 53, 3-10, 2008.

Labat, D., Goddéris, Y., Probst, J. L., and Guyot, J. L.: Evidence for global runoff increase related to climate warming, Adv. Water Resour., 27, 631-642, doi:10.1016/j.advwatres.2004.02.020, 2004.

Legates, D. R., Lins, H. F., and McCabe, G. J.: Comments on "Evidence for global runoff increase related to climate warming" by Labat et al., Adv. Water Resour., 28, 1310-1315, doi:10.1016/j.advwatres.2005.04.006, 2005.
Legendre, P. and Legendre, L.: Numerical Ecology, Elsevier, Amsterdam, Netherlands and Oxford, United Kingdom, 853 pp., 2012.

Li, D., Pan, M., Cong, Z., Zhang, L., and Wood, E.: Vegetation control on water and energy balance within the Budyko framework, Water Resour. Res., 49, 969-976, doi:10.1002/wrcr.20107, 2013.

$\mathrm{Li}, \mathrm{Z}$. and Mölders, N.: Interaction of impacts of doubling $\mathrm{CO}_{2}$ and changing regional land-cover on evaporation, precipitation, and runoff at global and regional scales, Int. J. Climatol., 28, 16531679, doi:10.1002/joc.1666, 2008.

Lo, M.-H. and Famiglietti, J. S.: Irrigation in California's Central Valley strengthens the southwestern U.S. water cycle, Geophys. Res. Lett., 40, 301-306, doi:10.1002/grl.50108, 2013.

McVicar, T. R., Roderick, M. L., Donohue, R. J., Li, L. T., Van Niel, T. G., Thomas, A., Grieser, J., Jhajharia, D., Himri, Y., Mahowald, N. M., Mescherskaya, A. V., Kruger, A. C., Rehman, S., and Dinpashoh, Y.: Global review and synthesis of trends in observed terrestrial near-surface wind speeds: Implications for evaporation, J. Hydrol., 416-417, 182-205, doi:10.1016/j.jhydrol.2011.10.024, 2012.

Milliman, J. D., Farnsworth, K. L., Jones, P. D., Xu, K. H., and Smith, L. C.: Climatic and anthropogenic factors affecting river discharge to the global ocean, 1951-2000, Global Planet. Change, 62, 187-194, doi:10.1016/j.gloplacha.2008.03.001, 2008.

Monteith, J. L.: Accommodation between transpiring vegetation and the convective boundary layer, J. Hydrol., 166, 251-263, 1995.

Mueller, B., Seneviratne, S. I., Jimenez, C., Corti, T., Hirschi, M., Balsamo, G., Ciais, P., Dirmeyer, P., Fisher, J. B., Guo, Z., Jung, M., Maignan, F., McCabe, M. F., Reichle, R., Reichstein, M., Rodell, M., Sheffield, J., Teuling, A. J., Wang, K., Wood, E. F., and Zhang, Y.: Evaluation of global observations-based evapotranspiration datasets and IPCC AR4 simulations, Geophys. Res. Lett., 38, L06402, doi:10.1029/2010g1046230, 2011.

Murray, S. J., Foster, P. N., and Prentice, I. C.: Evaluation of global continental hydrology as simulated by the Land-surface Processes and eXchanges Dynamic Global Vegetation Model, Hydrol. Earth Syst. Sci., 15, 91-105, doi:10.5194/hess-15-91-2011, 2011.

Murray, S. J., Watson, I. M., and Prentice, I.C.: The use of dynamic global vegetation models for simulating hydrology and the potential integration of satellite observations, Prog. Phys. Geog., 37, 63-97, doi:10.1177/0309133312460072, 2013.

Oki, T. and Kanae, S.: Global hydrological cycles and world water resources, Science, 313, 1068-1072, doi:10.1126/science.1128845, 2006.

Oliveira, P. J. C., Davin, E. L., Levis, S., and Seneviratne, S. I.: Vegetation-mediated impacts of trends in global radiation on land hydrology: a global sensitivity study, Global Change Biol., 17, 3453-3467, doi:10.1111/j.1365-2486.2011.02506.x, 2011.

Peel, M. C. and McMahon T. A.: Continental runoff: a quality-controlled global runoff data set, Nature, 444, E14, doi:10.1038/nature05480, 2006.

Peel, M. C., McMahon, T. A., and Finlayson, B. L.: Vegetation impact on mean annual evapotranspiration at a global catchment scale, Water Resour. Res., 46, W09508, doi:10.1029/2009WR008233, 2010. 
Piao, S., Friedlingstein, P., Ciais, P., de Noblet-Ducoudre, N., Labat, D., and Zaehle, S.: Changes in climate and land use have a larger direct impact than rising $\mathrm{CO}_{2}$ on global river runoff trends, Proc. Natl. Acad. Sci., 104, 15242-15247, doi:10.1073/pnas.0707213104, 2007.

Prentice, I. C. and Cowling, S. A.: Dynamic global vegetation models, in: Encyclopedia of Biodiversity, 2nd Edn., edited by: Levin, S. A., Academic Press, 607-689, 2013.

Prentice, I. C., Kelley, D. I., Foster, P. N., Friedlingstein, P., Harrison, S. P., and Bartlein, P. J.: Modeling fire and the terrestrial carbon balance, Global Biochem. Cy., 25, GB3005, doi:10.1029/2010gb003906, 2011.

Raupach, M. R.: Equilibrium evaporation and the convective boundary layer, Boundary-Layer Meteorol., 96, 107-141, 2000.

Raupach, M. R.: Combination theory and equilibrium evaporation, Quart. J. Roy. Meteorol. Soc., 127, 1149-1181, 2001.

Roderick, M. L. and Farquhar, G. D.: The cause of decreased pan evaporation over the past 50 years, Science, 298, 1410-1411, doi:10.1126/science.1075390, 2002.

Roderick, M. L. and Farquhar, G. D.: Changes in Australian pan evaporation from 1970 to 2002, Int. J. Climatol., 24, 1077-1090, doi:10.1002/joc.1061, 2004.

Rost, S., Gerten, D., Bondeau, A., Lucht, W., Rohwer, J., and Schaphoff, S.: Agricultural green and blue water consumption and its influence on the global water system, Water Resour. Res., 44, W09405, doi:10.1029/2007wr006331, 2008.

Rudolf, B., Hauschild, H., Rueth, W., and Schneider, U.: Terrestrial precipitation analysis: operational method and required density of point measurements, in: Global Precipitations and Climate Change, edited by: Desbois, M. and Desalmond, F., NATO ASI Series I, Vol. 20, Springer-Verlag, 173-186, 1994.

Schneider, U., Fuchs, T., Meyer-Christoffer, A., and Rudolf, B.: Global Precipitation Analysis Products of the GPCC, Global Precipitation Climatology Centre (GPCC), Deutscher Wetterdienst, Offenbach am Main, Germany, 2008.

Sellers, P. J., Bounoua, L., Collatz, G. J., Randall, D. A., Dazlich, D. A., Los, S. O., Berry, J. A., Fung, I., Tucker, C. J., Field, C. B., and Jensen, T. G.: Comparison of radiative and physiological effects of doubled atmospheric $\mathrm{CO}_{2}$ on climate, Science, 271, 1402-1406, doi:10.1126/science.271.5254.1402, 1996.

Seneviratne, S. I., Corti, T., Davin, E. L., Hirschi, M., Jaeger, E. B., Lehner, I., Orlowsky, B., and Teuling, A. J.: Investigating soil moisture-climate interactions in a changing climate: A review, Earth-Sci. Rev., 99, 125-161, doi:10.1016/j.earscirev.2010.02.004, 2010.

Sheffield, J. and Wood, E. F.: Global trends and variability in soil moisture and drought characteristics, 1950-2000, from observation-driven simulations of the terrestrial hydrologic cycle, J. Climate, 21, 432-458, doi:10.1175/2007JCLI1822.1, 2008.

Sitch, S., Smith, B., Prentice, I. C., Arneth, A., Bondeau, A., Cramer, W., Kaplans, J. O., Levis, S., Lucht, W., Sykes, M. T., Thonicke, K., and Venevsky, S.: Evaluation of ecosystem dynamics, plant geography and terrestrial carbon cycling in the LPJ dynamic global vegetation model, Global Change Biol., 9, 161$185,2003$.

Teuling, A. J., Hirschi, M., Ohmura, A., Wild, M., Reichstein, M., Ciais, P., Buchmann, N., Ammann, C., Montagnani, L., Richardson, a. D., Wohlfahrt, G., and Seneviratne, S. I.: A regional perspective on trends in continental evaporation, Geophys. Res. Lett., 36, L02404, doi:10.1029/2008GL036584, 2009.

Ukkola, A. M. and Murray, S. J.: Hydrological evaluation of the LPX dynamic global vegetation model for small river catchments in the UK, Hydrol. Process., in press, 2013.

Uppala, S. M., Kållberg, P. W., Simmons, A. J., Andrae, U., Bechtold, V. D. C., Fiorino, M., Gibson, J. K., Haseler, J., Hernandez, A., Kelly, G. a., Li, X., Onogi, K., Saarinen, S., Sokka, N., Allan, R. P., Andersson, E., Arpe, K., Balmaseda, M. A., Beljaars, A. C. M., van de Berg, L., Bidlot, J., Bormann, N., Caires, S., Chevallier, F., Dethof, A., Dragosavac, M., Fisher, M., Fuentes, M., Hagemann, S., Holm, E., Hoskins, B. J., Isaksen, L., Jansses, P. A. E. M., Jenne, R., McNally, A. P., Mahfouf, J.-F., Morcrette, J.-J., Rayner, N. A., Saunders, R. W., Simon, P., Sterl, A., Trenberth, K. E., Untch. A., Vasiljevic, D., Viterbo, P., and Woollen, J.: The ERA-40 re-analysis, Q. J. Roy. Meteor. Soc., 131, 29613012, doi:10.1256/qj.04.176, 2005.

Wang, K. and Dickinson, R. E.: A review of global terrestrial evapotranspiration: observation, modeling, climatology and climatic variability, Rev. Geophys., 50, RG2005, doi:10.1029/2011RG000373, 2012.

Wang, K., Dickinson, R. E., Wild, M., and Liang, S.: Evidence for decadal variation in global terrestrial evapotranspiration between 1982 and 2002: 2. Results, J. Geophys. Res., 115, D20113, doi:10.1029/2010JD013847, 2010.

Weedon, G. P., Gomes, S., Viterbo, P., Shuttleworth, W. J., Blyth, E., Österle, H., Adam, J. C., Bellouin, N., Boucher, O., and Best, M.: Creation of the WATCH Forcing Data and its use to assess global and regional reference crop evaporation over land during the twentieth century, J. Hydrometeorol., 12, 823-848, doi:10.1175/2011JHM1369.1, 2011.

Wild, M., Grieser, J., and Schär, C.: Combined surface solar brightening and increasing greenhouse effect support recent intensification of the global land-based hydrological cycle, Geophys. Res. Lett., 35, L17706, doi:10.1029/2008gl034842, 2008.

Wohl, E., Barros, A., Brunsell, N., Chappell, N. A., Coe, M., Giambelluca, T., Goldsmith, S., Harmon, R., Hendrickx, J. M. H., Juvik, J., McDonnell, J., and Ogden, F.: The hydrology of the humid tropics, Nat. Clim. Change, 2, 655-662, doi:10.1038/nclimate1556, 2012.

$\mathrm{Xu}$, C.-Y. and Singh, V. P.: Evaluation and generalization of radiation-based methods for calculating evaporation, Hydrol. Process., 14, 339-349, 2000.

Zeng, Z., Piao, S., Lin, X., Yin, G., Peng, S., Ciais, P., and Myneni, R. B.: Global evapotranspiration over the past three decades: estimation based on the water balance equation combined with empirical models, Environ. Res. Lett., 7, 014026, doi:10.1088/17489326/7/1/014026, 2012.

Zhang, L. K., Hickel, K., Dawes, W. R., Chiew, F. H. S., Western, A. W., and Briggs P. R.: A rational function approach for estimating mean annual evapotranspiration, Water Resour. Res., 40, W02502, doi:10.1029/2003WR002710, 2004.

Zhang, Y., Leuning, R., Chiew, F. H. S., Wang, E., Zhang, L., Liu, C., Sun, F., Peel, M. C., Shen, Y., and Jung, M.: Decadal trends in evaporation from global energy and water balances, J. Hydrometeorol., 13, 379-391, doi:10.1175/JHM-D-11-012.1, 2012.

Zobler, L.: A world soil file for global climate modelling, NASA Technical Memorandum 87802, NASA/GISS, New York, USA, 32 pp., 1986. 